\title{
AC 2007-2343: ASSESSMENTS FOR THREE PERFORMANCE AREAS IN CAPSTONE ENGINEERING DESIGN
}

\section{Denny Davis, Washington State University}

Denny Davis is Professor of Bioengineering and Co-director of the Engineering Education Research Center at Washington State University

Steven Beyerlein, University of Idaho

Steven Beyerlein is Professor of Mechanical Engineering at the University of Idaho

\section{Olakunle Harrison, Tuskegee University}

Olakunle Harrison is Associate Professor of Mechanical Engineering at Tuskegee University

\section{Phillip Thompson, Seattle University}

Phillip Thompson is Associate Professor of Civil and Environmental Engineering at Seattle University

\section{Michael Trevisan, Washington State University}

Michael Trevisan is Professor of Educational Leadership and Counseling Psychology and Director of the Assessment and Evaluation Center at Washington State University 


\title{
Assessments for Three Performance Areas in Capstone Engineering Design
}

\begin{abstract}
Capstone engineering design courses occupy pivotal positions in every engineering baccalaureate degree program. They are critical to preparing graduates with professional skills needed for innovative, responsible practice in a global environment, and they provide vital assessment data for ABET accreditation of degree programs. This paper describes assessment instruments developed for capstone engineering design courses, filling a crucial gap facing design educators. Seven assessment exercises are presented to address three areas of performance for capstone engineering design. Each exercise is accompanied by a scoring rubric structured around performance factors and five levels of performance. Suggestions given for utilization for formative and summative purposes make these assessments valuable for guiding student learning and assigning performance scores or grades. These assessments constitute foundational parts of an assessment system for capstone engineering design courses.
\end{abstract}

\section{Introduction}

National leaders have called for reform of engineering education to prepare engineering graduates for the competitive global market place ${ }^{1,2}$. Among capabilities cited as deficient in student preparation are professional skills and abilities to innovate technical products in the context of business conditions ${ }^{3,4}$. Oftentimes, these topics are not given appropriate attention in engineering programs.

Important professional skill development is often assigned to capstone engineering design courses. These courses are the culminating experiences for undergraduate engineering students, and they often incorporate client-driven design projects that have significant professional challenges. Surveys of capstone design instructors, however, indicate that instructional focus and assessment of student learning vary greatly, depending on instructor preferences and abilities. Seldom are comprehensive outcomes defined for these courses ${ }^{5}$. This raises concerns regarding student preparation and ABET accreditation, both of which require assessment of design and many professional outcomes ${ }^{6}$.

More than a decade ago, Richard Stiggins made a strong case for classroom assessment as the cornerstone to effective instruction ${ }^{7}$. He argues that with clear achievement targets and appropriate assessment strategies, students are more likely to increase their achievement since they understand what is expected of them. In addition, Black and Wiliam ${ }^{8}$, studying classroom assessment practices across grades, disciplines, and countries, documented overwhelming evidence that classroom assessment can enhance student achievement and academic well being. Therefore, high quality classroom assessment in capstone design courses is vital due to pivotal roles that capstone design courses play in engineering curricula. Also, because these courses are a required part of accredited engineering programs in the US, they provide a rich environment for assessing a variety of student learning outcomes and associated program achievements. 
A number of researchers report strategies for assessing student performance in capstone engineering design courses ${ }^{9-13}$. Some instructors assess student work in capstone design courses by focusing more on design steps than on the quality of design products ${ }^{5}$, while others focus on design products with little attention given to design processes ${ }^{14}$. However, success after graduation requires engineers to produce high quality products while also refining their processes and developing professionally to support continuous improvement of product quality. This argues the importance of capstone design course outcomes related to both student learning and product development.

The authors of this paper have a record of developing instructional materials and assessments for engineering design. As part of the TIDEE \{ Transferable Integrated Design Engineering Education] consortium, they have defined design learning outcomes based on surveys of capstone design instructors and industry representatives ${ }^{4,15}$. They also defined design learning outcomes and created assessments for the first two years of engineering design curricula ${ }^{16}$. Currently, they are leading a National Science Foundation project, "Transferable Assessments for Capstone Engineering Design" which is developing and testing research-based assessments for capstone design courses across disciplines and institutions. In this process, they found that few engineering faculty use proven assessments for formative assessment in capstone design courses $^{17}$. This finding justified development of a cognitive development model for capstone $\operatorname{design}^{18}$ and a framework for guiding development of sound assessments for capstone design courses ${ }^{19}$.

\section{Goal}

The goal of the NSF project, "Transferable Assessments for Capstone Engineering Design," is to produce versatile, sound classroom assessment instruments for assessing student achievement in capstone engineering design courses. The goal of this paper is to present the assessments produced by this project. This paper presents a set of three assessments, comprised of specific assessment exercises and corresponding scoring rubrics based on the cognitive development model and assessment framework established earlier. The paper also offers suggestions for use of assessments in formative and summative applications.

\section{Areas of Performance}

Capstone design courses must produce capable students and quality design products. Researchers report that design performances of experts are evidenced by their thought processes, personal abilities, understanding of important requirements, and capabilities to deliver valuable products. The authors, with the help of design education consultants, defined four areas of performance that encompass essential aspects of engineering design performances:

Learner development outcomes are defined under two areas of performance:

(1) Personal capacity: Individuals performing and improving individual skills essential to engineering design

(2) Team processes: Teams developing and implementing collective processes that support team productivity in design 
Solution development outcomes are defined under two additional areas of performance:

(3) Solution requirements: Definition of targeted design solution performance and features expected to satisfy stakeholder needs and constraints

(4) Solution assets: Results from a design project that meet needs and deliver satisfaction and value to key project stakeholders

For each of these areas, performance criteria were defined to articulate performances desired in a capstone engineering design course. These definitions embrace the critical factors relevant to each of these areas of performance, so they also suggest a framework for measuring achievement. Performance criteria and corresponding factors identified for each performance area are listed below.

\section{$\underline{\text { Personal Capacity }}$}

Performance Criterion: "Individuals accomplish challenging goals related to design by employing goal-driven initiative, competence in problem solving, integrity and professionalism, and ongoing reflective development of their personal abilities."

Factors: initiative, problem solving, professionalism, self-growth

\section{$\underline{\text { Team Processes }}$}

Performance Criterion: "The team achieves challenging goals in productivity and team function by strategic use of team resources, synergistic collaboration, decisions that add real value, and assessment-driven refinement of processes."

Factors: resource management, collaboration, decision making, process improvement

\section{$\underline{\text { Solution Requirements }}$}

Performance Criterion: "Stated requirements reflect an in-depth understanding of customer needs, business issues, state of the technology, and societal concerns about the solution, while providing clear targets for the development of a valuable solution."

Factors: voice of customer, voice of business, voice of technology, voice of society

\section{$\underline{\text { Solution Assets }}$}

Performance Criterion: "Design solutions meet or exceed expectations of stakeholders by delivering proven value in desired functionality, economic benefits, implementation feasibility, and favorable impacts on society."

Factors: proof of performance, proof of profitability, proof of feasibility, proof of impact 


\section{Assessment Instruments}

Assessment instruments have been developed for three of the four performance areas; only the solution assets area has not been addressed at this time. Assessment exercises are derived to address critical factors within the performance area. For example, for the personal capacity performance area, one assessment exercise addresses students' initiative and self-growth (while also addressing the ABET outcome of lifelong learning): a self-growth paper. A second exercise addresses problem solving and professionalism (while also addressing the ABET ethics and professionalism outcome: a professional practices paper. The available assessment exercises are summarized in Table 1.

Table 1: Summary of Capstone Design Course Assessments Available

\begin{tabular}{|c|c|c|c|}
\hline $\begin{array}{l}\text { Performance } \\
\text { Area }\end{array}$ & $\begin{array}{l}\text { Assessment } \\
\text { Exercise }\end{array}$ & Description of Assessment & ABET Outcomes Addressed \\
\hline \multirow{2}{*}{$\begin{array}{l}\text { Personal } \\
\text { Capacity }\end{array}$} & $\begin{array}{l}\text { Personal } \\
\text { Growth }\end{array}$ & $\begin{array}{l}400-500 \text { word essay: } \\
\text { reflective analysis of growth } \\
\text { during project }\end{array}$ & $\begin{array}{l}\text { - } 3 \text { g Communication } \\
\text { (written) } \\
\circ \text { 3i Lifelong learning } \\
\end{array}$ \\
\hline & $\begin{array}{l}\text { Professional } \\
\text { Practices }\end{array}$ & $\begin{array}{l}400-500 \text { word essay: analysis } \\
\text { of professional/ethical issues } \\
\text { in project }\end{array}$ & $\begin{array}{l}\circ \text { 3f Professional \& ethical } \\
\circ 3 \mathrm{~g} \text { Communication } \\
\text { (written) }\end{array}$ \\
\hline \multirow{2}{*}{$\begin{array}{l}\text { Team } \\
\text { Processes }\end{array}$} & $\begin{array}{l}\text { Team } \\
\text { Member } \\
\text { Citizenship }\end{array}$ & $\begin{array}{l}\text { Short answer: rating of } \\
\text { member contributions; } \\
\text { analysis for improvement }\end{array}$ & - 3d Teamwork \\
\hline & $\begin{array}{l}\text { Team Process } \\
\text { Development }\end{array}$ & $\begin{array}{l}\text { Short answer: analysis of } \\
\text { strong and weak team } \\
\text { processes }\end{array}$ & ○ 3d Teamwork \\
\hline \multirow{3}{*}{$\begin{array}{l}\text { Solution } \\
\text { Requirements }\end{array}$} & $\begin{array}{l}\text { Stakeholder } \\
\text { Needs }\end{array}$ & $\begin{array}{l}\text { Short answer: identification } \\
\text { of key stakeholders and needs }\end{array}$ & - 3h Solution impact \\
\hline & $\begin{array}{l}\text { Project } \\
\text { Outcomes }\end{array}$ & $\begin{array}{l}\text { Short response: statement of } \\
\text { problem, expected outcomes, } \\
\text { and benefits }\end{array}$ & - 3h Solution impact \\
\hline & $\begin{array}{l}\text { Solution } \\
\text { Specifications }\end{array}$ & $\begin{array}{l}\text { Short response: list of high } \\
\text { priority requirements with } \\
\text { targeted outcomes }\end{array}$ & - 3h Solution impact \\
\hline
\end{tabular}

Details of the assessment exercises are too extensive for inclusion in this paper, so condensations are presented below. For details, refer to the WSU Engineering Education Research Center web site at: www.eerc.wsu.edu/ASA .

\section{Personal Capacity}

\section{Personal Growth paper}

Write a 400-to-500 word reflective essay around a significant personal growth opportunity you encountered in your project this term. Begin by identifying a situation that challenged your knowledge, skills, or attitudes. Explain how you recognized the need for personal growth and actions you took to address the challenge: your thoughts, judgments, goal 
setting, search for help, and steps to overcome the challenge. Describe impacts of your actions: learning, insights, impacts on the project, etc. Also reflect on how your challengedriven personal growth experience will affect your ability to address personal challenges in the future.

Professional Practices paper

Write a 400-to-500 word paper describing your analysis of an ethical or professional situation encountered in your project this term. (Note: These issues can often arise around decisions on product cost or functionality, user safety, intellectual property, codes or standards, manufacturing processes, product disposal, marketing practices, product testing, or client interactions). If you did not personally address an ethical/professional dilemma, identify one from your project that should be addressed, then analyze this situation.

\section{$\underline{\text { Team Processes }}$}

Team Member Citizenship

Rate members of your team (including yourself) on their actions contributing to an effective team. In table each cell, assign a person a rating (1-5) for each of the 12 actions, based on definitions given.

Next, identify members' percent contributions to project achievements this term.

For each of your team members (including yourself):

a. Assess a key strength: Describe what makes it strong, and identify impacts this strength has in making your team work together better.

b. Recommend an improvement: Define specific actions to produce a desired improvement, and describe expected benefits these actions will have on making a better team.

Team Process Development

Describe one of your most effective team processes for achieving high team productivity. Identify and describe the process, and explain what worked well and why. Your explanations will be strongest when they show understanding of what makes this team process effective in enhancing team productivity.

Explain how to improve one of your weaker team processes that is important to achieving your team's goals. Name the team process, explain what improvements are needed, and describe steps the team should take to achieve desired improvement. Your explanations will be strongest when they show understanding of how to improve the process' effectiveness.

\section{$\underline{\text { Solution Requirements }}$}

Stakeholder Needs

In each box provided, identify a person or group that fits that particular stakeholder category: customer/user, business/financial, technical, or society. Then define that person or group's most important needs that should be satisfied by your design solution. Demonstrate 
your understanding of key people in each of these four categories and needs they perceive to be most crucial to the success of your project.

\section{Project Outcomes}

Write a brief paragraph that describes the problem or opportunity being addressed, what will be delivered by your design team, and the benefits that should come from your solution. Show your understanding of the core problem, the solution, and benefits offered by the solution.

\section{Solution Specifications}

Identify the most important requirements to be met by your solution. Be specific enough so these can be used to determine your solution's success (e.g., cite standards, codes, or norms to be met). For each:

(a) Give a brief definition or description of the specification

(b) Give a value or other evidence indicating when the specification has been achieved

\section{Assessment Scoring}

Student performance on each assessment is scored based on the performance criteria for the respective performance area and the scope of the specific assessment exercise. A five-point scoring rubric has been defined for each assessment exercise to clarify performances at levels ranging from novice to expert.

Table 2 presents an example scoring rubric. This rubric for the Professional Growth paper is used to score the paper with respect to (a) personal growth achievement and understanding and (b) written communication. For the personal growth score, factors considered include: the student's understanding of the need, goals for achieving growth, plan to achieve growth, and demonstrated achievement of growth. For the written communication performance, word usage, spelling and punctuation, sentence and paragraph structure, and overall effectiveness are considered. For each of these two scores, the scorer may check levels reflected by the work for each factor and then assign a score ( 1 to 5 ) that represents the overall level of performance. Space is also provided for writing comments and suggestions for formative feedback.

A similarly structured rubric is defined for each of the seven assessment exercises associated with the personal capacity, team processes, and solution requirements areas of performance. Each uses a five-point scale for each factor identified for the performance being scored. To conserve space in this paper, a list of factors used in scoring each exercise is presented in Table 3. Details of rubrics may be found at the project website at: www.eerc.wsu.edu/ASA. 
Table 2: Scoring Rubric for Personal Growth Paper

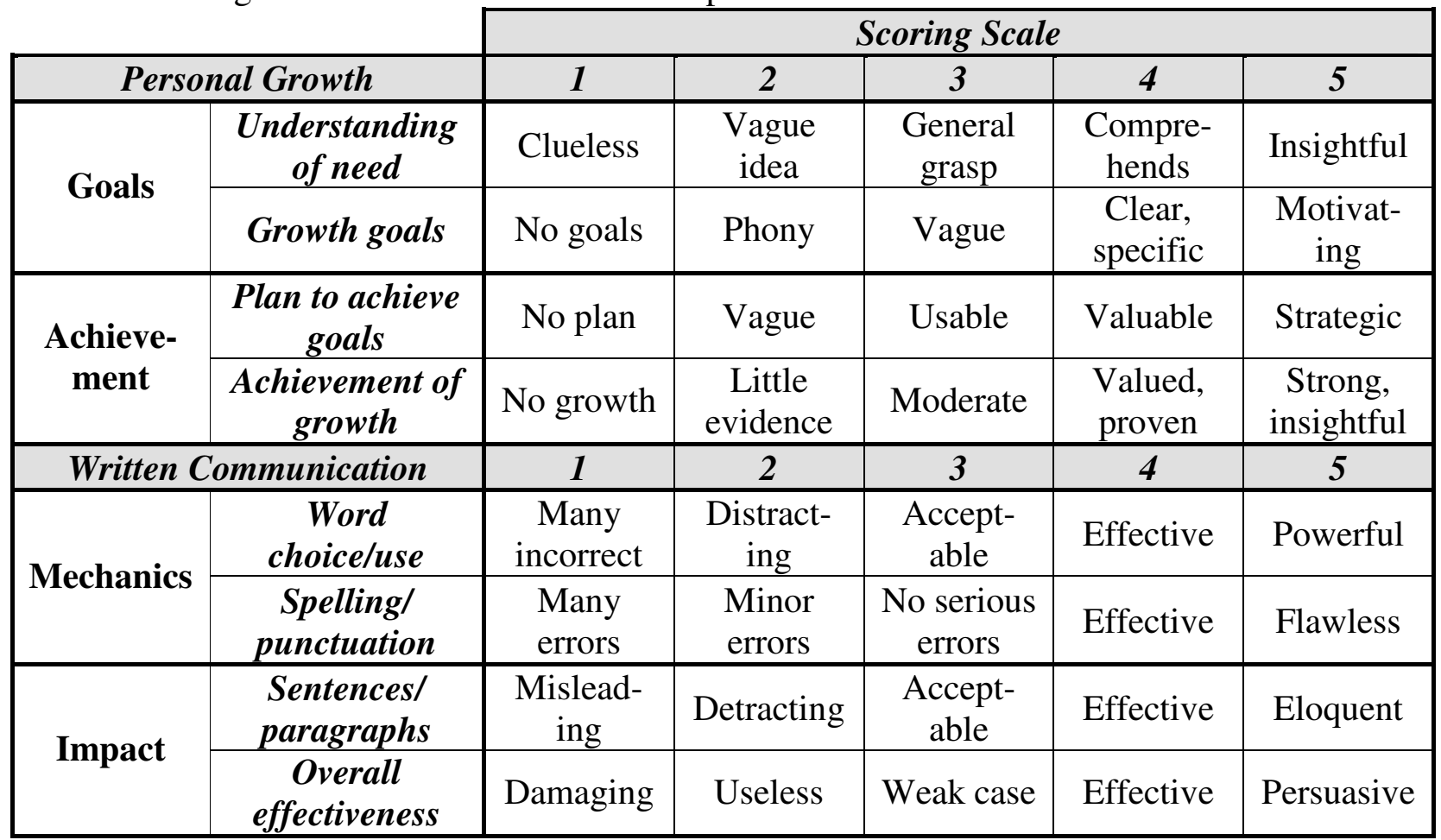

Personal Growth Score (1 - 5):

Written Communication Score $(1-5)$ :

\section{Assessment Utilization}

In general, classroom assessments may be used for formative feedback or for summative evaluation of performances. The capstone engineering design assessment exercises and scoring for the capstone engineering design assessments are versatile enough to be used for either purpose. According to Stiggins, the purpose of the assessment must be clearly understood by assessor and assessee for effective results to be achieved ${ }^{7}$. Baehr also emphasizes that formative assessment focus on providing feedback valued by the assessee and, ideally, providing formative assessment should not provide a score ${ }^{20}$. Thus, depending upon the intended purpose, the capstone design assessments should be handled differently. 
Table 3: Performance Factors Used in Scoring Assessment Exercises

\begin{tabular}{|c|c|}
\hline Assessment Exercise & Performance Factors Used in the Rubric \\
\hline Personal Growth Paper & $\begin{array}{l}\text { Personal Growth: understanding of need, growth goals, plan to achieve } \\
\text { goals, achievement of growth } \\
\text { Written Communication: word choices/use, spelling, punctuation, } \\
\text { sentences/paragraphs, overall effectiveness }\end{array}$ \\
\hline $\begin{array}{l}\text { Professional Practices } \\
\text { Paper }\end{array}$ & $\begin{array}{l}\text { Professional Practices: understanding issues, ethics/codes/policies, } \\
\text { reasoning, outcome achieved } \\
\text { Written Communication: word choices/use, spelling, punctuation, } \\
\text { sentences/paragraphs, overall effectiveness }\end{array}$ \\
\hline $\begin{array}{l}\text { Team Member } \\
\text { Citizenship }\end{array}$ & $\begin{array}{l}\text { Rating Member Contributions: own contribution level, all member } \\
\text { contribution levels, own value added, own vs. others' views } \\
\text { Improving Member Contributions: description of strengths, impacts of } \\
\text { strengths, actions for improving, expected benefits }\end{array}$ \\
\hline $\begin{array}{l}\text { Team Process } \\
\text { Development }\end{array}$ & $\begin{array}{l}\text { Effective Process: evidence of strength, understanding of strength } \\
\text { Proposed Improvements: understanding of need, plan for improvement }\end{array}$ \\
\hline Stakeholder Needs & $\begin{array}{l}\text { Customer/User: need fit to group, understanding of needs } \\
\text { Business/Financial: need fit to group, understanding of needs } \\
\text { Technical: need fit to group, understanding of needs } \\
\text { Society: need fit to group, understanding of needs }\end{array}$ \\
\hline Project Outcomes & $\begin{array}{l}\text { Problem Definition: scope of project, understanding of problem } \\
\text { Solution Envisioned: technical elements, non-technical elements } \\
\text { Solution Benefits: technical benefits, non-technical benefits }\end{array}$ \\
\hline Solution Specifications & $\begin{array}{l}\text { Functional Performance: extent addressed, specificity of target } \\
\text { Financial or Business: extent addressed, specificity of target } \\
\text { Technical Feasibility: extent addressed, specificity of target } \\
\text { Social, Ethical, Professional: extent addressed, specificity of target }\end{array}$ \\
\hline
\end{tabular}

For effective use as formative assessments, the assessment exercises should focus on providing students feedback to guide their improvement. This process may follow the following steps:

1. Inform students of performance expectations for the outcome being learned. This can be achieved by providing them a statement of the performance criterion for this area of performance.

2. Provide students examples that represent a range of performances related to the outcome being addressed. Ask students (perhaps, in pairs) to identify feature in the examples that distinguished better from poorer performances. Share and discuss these perceptions in class.

3. Administer the assessment exercise so students articulate their understanding with respect to their project experiences. Collect student responses. 
4. Ask students to exchange their work and to assess one another's performance using the rubric associated with the exercise. Ask the assessors to assign a performance score and to write specific comments for improving the performance. Return these to the student whose work was assessed.

5. Collect the student work and assessment feedback provided by a peer. Review these and add instructor comments to the scoring sheet for the benefit of the student being assessed.

6. Return the assessment and feedback (scoring) sheets to students. Ask students (in class) to share new insights they gained about the outcome for which they were assessed.

For effective use as summative assessments, the assessment exercises should focus on the assignment of scores that best represent student performances. These judgments need to be made by the instructor, but they also should be built on sound understanding of the students regarding criteria for this evaluation. Thus, a recommended approach is:

1. Inform students of performance expectations early in the course and prior to the administration of the assessment exercise. A useful class discussion prior to assessment administration is the criteria to be used for evaluating performances of the outcome of concern. Allow students to articulate their understanding of criteria, then hand out the scoring rubric to be used. Discuss similarities and differences in understanding of the criteria.

2. Administer the assessment exercise to obtain evidence for student performance. One may ask students to identify themselves only by their student identification numbers so that later scoring will be treated anonymously.

3. Score student work by considering each factor identified on the scoring rubric. Check the level of performance for each factor, and make comments regarding issues that affected each level selected.

4. Assign an overall score that represents the performance of the student. This may not be the mean of scores for factors, especially if some factors are less important or less useful for this student's performance.

Use of the same assessment exercises for both formative and summative purposes may be useful to document changes in student understanding and development over a given time period. For example, use of Solution Requirements exercises early in the project period and again as the detail design begins can demonstrate maturing definitions of the solution requirements. In some cases, one may ask teams to complete the assessment, while at other times, individuals should complete the exercise. This allows team members to more fully understand different perceptions of team members regarding the intent of the project.

Table 4 suggests ways and times for administering each of the assessment exercises. As noted, administration of exercises to individuals and to teams can be used to achieve different learning. Individual responses facilitate discussions among members to reveal different opinions or misunderstandings. Administration to individuals after earlier administration to teams reveals student understanding of what the team agreed upon and allows grading of individual student performance. 
Table 4: Recommended Uses of Capstone Design Assessment Exercises

\begin{tabular}{|c|c|c|}
\hline Assessment Exercise & Formative Usage & Summative Usage \\
\hline Personal Growth & $\begin{array}{l}\text { Administer after students have } \\
\text { identified solution requirements; } \\
\text { help students set plans for growth }\end{array}$ & $\begin{array}{l}\text { Administer near end of a class } \\
\text { term; document growth achieved } \\
\text { and stimulate mindset for lifelong } \\
\text { learning }\end{array}$ \\
\hline Professional Practices & $\begin{array}{l}\text { Administer after students have } \\
\text { identified solution requirements; } \\
\text { help students identify needs to } \\
\text { learn and apply codes, standards, } \\
\text { ethical reasoning }\end{array}$ & $\begin{array}{l}\text { Administer near end of class term; } \\
\text { document substantive use of } \\
\text { codes, standard, ethical reasoning } \\
\text { and value these elements of } \\
\text { product development }\end{array}$ \\
\hline $\begin{array}{l}\text { Team Member } \\
\text { Citizenship }\end{array}$ & $\begin{array}{l}\text { Administer after first major team } \\
\text { assignment is submitted; } \\
\text { summarize anonymous data for } \\
\text { each student } \\
\text { Administer after mid-term; } \\
\text { photocopy each member's } \\
\text { responses for whole team }\end{array}$ & $\begin{array}{l}\text { Administer at end of term; use to } \\
\text { document each team member's } \\
\text { contributions and abilities to give } \\
\text { constructive criticism over the } \\
\text { term }\end{array}$ \\
\hline $\begin{array}{l}\text { Team Process } \\
\text { Development }\end{array}$ & $\begin{array}{l}\text { Administer mid-term; use to bring } \\
\text { focus on important processes, } \\
\text { what constitutes quality, and need } \\
\text { for continuous refinement }\end{array}$ & $\begin{array}{l}\text { Administer at end of term; use to } \\
\text { document quality and } \\
\text { understanding of team's processes, } \\
\text { and improvements }\end{array}$ \\
\hline Stakeholder Needs & $\begin{array}{l}\text { Administer individually shortly } \\
\text { after project assignment; use to } \\
\text { prompt students to consider broad } \\
\text { impacts to be addressed }\end{array}$ & $\begin{array}{l}\text { Administer by team after teams do } \\
\text { background research; use to } \\
\text { formalize a consensus set of } \\
\text { stakeholders }\end{array}$ \\
\hline Project Outcomes & $\begin{array}{l}\text { Administer individually and share } \\
\text { in team shortly after project } \\
\text { assignment; use to help students } \\
\text { see big picture for their project }\end{array}$ & $\begin{array}{l}\text { Administer by team prior to } \\
\text { requiring solution specifications to } \\
\text { document project goal before } \\
\text { defining specs }\end{array}$ \\
\hline $\begin{array}{l}\text { Solution } \\
\text { Specifications }\end{array}$ & $\begin{array}{l}\text { Administer by team midway } \\
\text { through term to facilitate } \\
\text { consensus definitions of solution } \\
\text { requirements }\end{array}$ & $\begin{array}{l}\text { Administer individually before } \\
\text { beginning detail design to } \\
\text { document member understanding } \\
\text { of solution requirements }\end{array}$ \\
\hline
\end{tabular}

\section{Conclusions}

Improvement of capstone engineering design courses depends upon having effective methods for measuring student performance and on implementing practices to encourage and guide student improvement. The seven assessment exercises presented to measure student achievement for three key areas of performance in capstone design courses provide the requisite tools for meeting this need. Each assessment is grounded in a cognitive development model for achievement targeted by reputable design educators and practitioners. Each is also suitable for either formative use or summative use, therefore providing a multi-facet toolkit for improving and 
grading performance. Pilot testing is underway to determine best practices for assessment implementation and scoring. In all, these assessment tools support continuous improvement of design education for three of four performance areas key to capstone engineering design.

\section{Acknowledgements}

Research defining outcomes, developing assessments, and testing assessments was funded by the Division of Undergraduate Education of the National Science Foundation under grant NSF/DUE 0404924.

\section{Bibliography}

1. The National Academies (2006). Rising above the gathering storm. Washington, DC: National Academies Press.

2. Anonymous (2006). The national engineering education research colloquies. Journal of Engineering Education, 95(4), 257.

3. National Academy of Engineering (2004). The engineer of 2020: Visions of engineering in the new century. Washington, DC.: The National Academies Press.

4. Davis, D., Beyerlein, S., and Davis, I. (2006). Deriving design course learning outcomes from a professional profile. International Journal of Engineering Education, 22(3), 439-446.

5. McKenzie, L.M. (2002). End-of-program assessment: An investigation of senior capstone design assessment practices. Doctoral Dissertation, College of Education, Washington State University, Pullman, WA

6. Accreditation Board for Engineering and Technology. (2006). Criteria for accrediting engineering programs. From www.abet.org

7. Stiggins, R. (1988). Revitalizing classroom assessment: The highest instructional priority. Phi Delta Kappan, 69, 363-368.

8. Black, P. and Wiliam, D. (1998). Assessment and classroom learning. Assessment in Education, 5(1), 7-74.

9. Powers, T., et al. (2002). Assessing team functioning in engineering education. Proceedings of the American Society for Engineering Education Annual Conference \& Exposition.

10. Sobek, D.K. (2002). Use of journals to evaluate student design processes. Proceedings of the American Society for Engineering Education Annual Conference \& Exposition.

11. Ohland, M., Pomeranz, H., and Feinstein, H. (2006). The comprehensive assessment of team member effectiveness: A new peer evaluation instrument. Proceedings of the American Society for Engineering Education Annual Conference \& Exposition.

12. Imbrie, P.K., Maller, S.J., and Immekus, J.C. (2005). Assessing team effectiveness. Proceedings of the American Society for Engineering Education Annual Conference \& Exposition.

13. Brackin, P. and Williams, J. (2001). Teaching and assessing team skills in a senior level design course. Proceedings of the American Society for Engineering Education Annual Conference \& Exposition.

14. Sobek, D.K. and Jain, J.K. (2004). Two instruments for assessing design outcomes of capstone projects. Proceedings of the American Society for Engineering Education Annual Conference \& Exposition.

15. Davis, D., Beyerlein, S., and Davis, I. (2005). Development and use of an engineer profile. Proceedings of the American Society for Engineering Education Annual Conference \& Exposition.

16. Davis, D., et al., Tidee design team readiness assessment - version 8. Washington State University. www.tidee.cea.wsu.edu

17. Trevisan, M., et al. (2006). A review of literature on assessment practives in capstone engineering design courses: Implications for formative assessment. Proceedings of the American Society for Engineering Education Annual Conference \& Exposition.

18. Davis, D., et al. (2006). A conceptual model for capstone engineering design performance and assessment. Proceedings of the American Society for Engineering Education Annual Conference \& Exposition.

19. Beyerlein, S., et al. (2006). Assessment framework for capstone design courses. Proceedings of the American Society for Engineering Education Annual Conference \& Exposition.

20. Baehr, M. (2005). Overview of assessment. In S. Beyerlein and Apple, D. (Eds.), Faculty guidebook: A comprehensive tool for improving faculty performance. 223. 